\title{
TRAGEDY IN ZOLITUDE - A LESSON FOR CONTEMPORARY SOCIETY
}

Sandra GUSTA, Department of Architecture and Building, Latvia University of AgricultureStreet Akadēmijas 19, Jelgava LV-3001, Latvia, sandra.gusta@1lu.lv

\begin{abstract}
Our modern society insists on the countryside reaching into the city. To make the urban environment more beautiful we make green roofs and improve the backyards by designing children's playgrounds and organizing recreational zones. We create a sustainable environment for future generations to have a comfortable life. However, one must not forget that the attractive green roofs of buildings are serious engineered structures. First and foremost the safety issues have to be taken into consideration during the construction and operation stages. On November 21, 2013 Maxima shopping center's roof collapsed in Riga, Latvia causing 54 deaths and creating international news. The collapse of the supermarket in the Latvian capital Riga has been described as "murder", by the country's president Andris Berzins. It is the deadliest disaster in Latvia since it regained independence in 1991. The causes of the collapse need to be studied in detail. This report is the authors' independent attempt to find the cause based on photographic evidence and literature observes. This article is based on a study conducted by the students and teachers of Latvia University of Agriculture. The article provides the reasons for this tragedy basing on the analysis. The author considers that the tragedy was the result of the coincidence of circumstances caused by mistakes in the calculation of building structures.
\end{abstract}

Keywords: durability of constructions, Maxima shopping centre, roof collapse, safety.

\section{INTRODUCTION}

According to the "Regulation (EU) No 305/2011 of the European parliament and of the council" of 9 March 2011 laying down harmonized conditions for the marketing of construction products and repealing the Council Directive 89/106/EEC Member States have introduced provisions, including requirements, relating not only to safety of buildings and other construction works but also to health, durability, energy economy, protection of the environment, economic aspects, and other important aspects in the public interest (Regulation..., 2011).

In ANNEX $I$ the BASIC REQUIREMENTS FOR CONSTRUCTION WORKS are mentioned: 1.Mechanical resistance and stability 2.Safety in case of fire 3.Hygiene, health and the environment 4.Safety and accessibility in use 5.Protection against noise 6.Energy economy and heat retention 7.Sustainable use of natural resources. The author offers to view some of them:

The 1st requirement - Mechanical resistance and stability.

The construction works must be designed and built in such a way that the loadings that are liable to act on them during their constructions and use will not lead to any of the following:

(a) collapse of the whole or part of the structure;

(b) major deformations to an inadmissible degree;

(c) damage to other parts of the construction works or to fittings or installed equipment as a result of major deformation of the load-bearing construction;

(d) damage by an event to an extent disproportionate to the original cause.

The fourth requirement - Safety and accessibility in use. The construction work must be designed in such a way that it does not present unacceptable risks of accidents or damage in service or in operation such as slipping, falling, collision, burns, electrocution, and injury from explosion and burglaries.

Most structural collapses are the result of human error and, as such, can be prevented. They are usually investigated by structural engineers to determine the cause, contributing factors, the trigger, and where the responsibility lies for errors in the design-construction-service history. (Ratay and Peraza, 2015).

Both construction companies and engineers tend not to talk about their mistakes and failures in the construction process. However, the error needs to be analyzed in order to escape the future similar cases.

Copyright (C) 2015 The Authors. Published by Aleksandras Stulginskis University. This is an open-access article distributed under the terms of the Creative Commons Attribution License (CC-BY 4.0), which permits unrestricted use, distribution, and reproduction in any medium, provided the original author and source are credited. 
The success of engineering outcomes largely depends on the quality of decisions made in the engineering process. The likelihood of poor decisions leading to unsatisfactory results, including safety issues, can be reduced by identifying potential problems in the associated decision processes. (Brown and Elms, 2015)

\section{MATERIALS AND METHODS}

Hypothesis: Safety and durability of constructions are the basic conditions for the buildings' longevity and sustainability in the future.

There is an increasing tendency of the sustainable development principle implementation in all Latvian companies including building, construction and architecture companies and this is what can be done, improved and developed by every company.

However, one should keep in mind that while implementing the sustainable development projects, the key is to ensure the safety of the structures, thus also human security.

The study used the following methods: analysis of available information, observation, sociological surveys, and interviews with experts and focus groups discussions.

In order to confirm or refute this statement, the following goal was set:

To analyze the causes and consequences of the tragedy in Zolitude using the information available to the author, so that lessons could be learnt by society to avoid similar tragedies in the future.

The objectives set in order to achieve the goal:

1. To analyze the theoretical basis for sustainable development and assess the necessity for it.

2. To analyze the causes and consequences of the tragedy in Zolitude.

3. To view similar structural collapse cases in Latvia and abroad.

\section{MAXIMA TRAGEDY IN RIGA}

On November 21, 2013 the roof of Maxima shopping center in Riga, Latvia collapsed, causing 54 deaths and international news. The collapse of a supermarket in the Latvian capital Riga has been described as "murder", by the country's president Andris Berzins. It is the deadliest disaster in Latvia since it became independent in 1991.

The causes of the collapse need to be studied in detail. This report is an independent attempt of the author and Rural Engineering Faculty students of Latvia University of Agriculture to find the causes based on photographic evidence, numerical and analytical calculations.
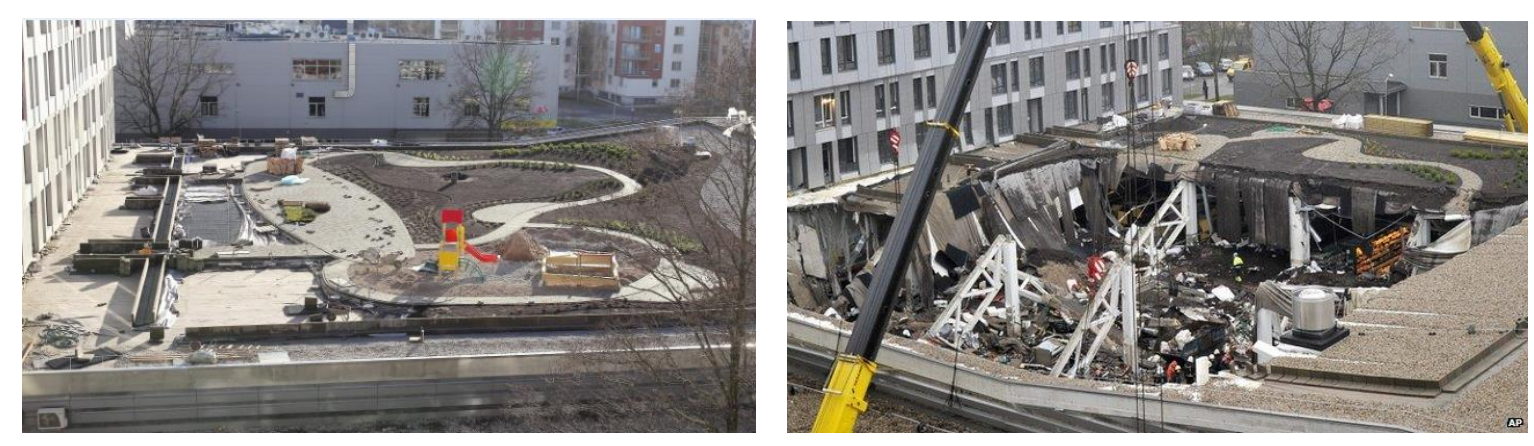

Figure 1. Maxima shopping center roof collapsed in Riga (before and after roof collapse). Photo by Gatis Smagars (Latvia...,2013)

The article provided the analysis of the reasons of this tragedy. The author considers that the tragedy was the result of the coincidence of circumstances, due to a mistake in the calculation of building structures. It is important to shed light on the reasons for the tragedy so that similar problems do not happen again in the future.

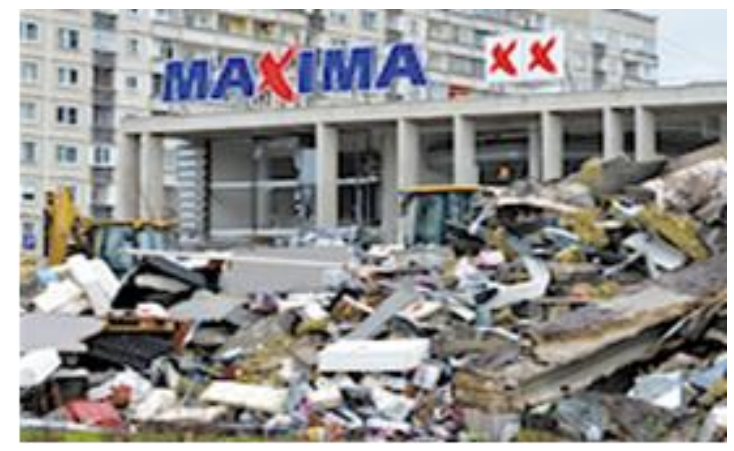

Figure 2. FLAWED: Inspections of buildings in Riga are exposing numerous problems (Lawsuit.., 2013) 


\section{MORE DEFENCES ARE FOUNDED}

Ongoing inspections by the Riga Construction Board of public buildings over the past several weeks have shown cracks of various sizes, specifically at 18 Rimi and 13 Maxima supermarkets in Riga. Overall, the Riga Construction Board has carried out inspections at more than 200 public buildings in Riga, including 100 Rimi, Supernetto and Maxima supermarkets, establishing "certain problems" in 31 of them.

Several years ago, the Riga City Council eliminated the local government's Construction Supervision Department, the functions of which were largely the same as the previously-eliminated State Construction Inspection, while the function of supervision of the construction process was completely handed over to local governments. The department, then part of the Riga City Council Construction Board, was liquidated in 2009. Riga City Council said this was due to a shortage of funds. It is notable that construction of the Maxima supermarket in Zolitude that collapsed began in 2010. The Construction Supervision Department's functions were not taken over by any other unit of the Riga City Council. It was a "political decision by the Riga City Council" to weaken the Construction Board so it would not impede the various construction projects implemented in Riga.

In late November, a 100 million lats Lawsuit was filed in Riga Regional Court against Maxima Latvia, construction company Re\&Re, the company Tineo - the owner of the collapsed Maxima supermarket building, real estate developer Homburg Zolitude, and Riga City Council. (Latvia...,2014)

\section{RESULTS AND DISCUSSION}

"Maxima" supermarket was not the only ruined building, where the Maxima construction team participated in. In 2011 the roof of one of the two recently completed "Cemex" factory warehouse collapsed causing millions of measurable losses.

The "Maxima" supermarket tragedy is largely similar to the disaster at the International Exhibition Centre (Międzynarodowe Targi Katowicka) in the Polish city of Katowice on 28 January 2006.

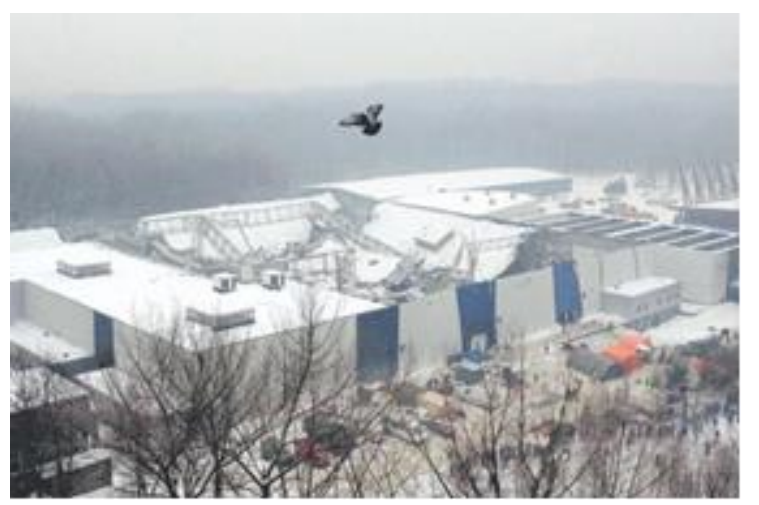

Figure 3. Tragedy in Katovice, Poland on 28 January 2006 (Kā Polijas..., 2013)

The investigation was completed in 2008, in late June. Katowice District Court in late July found the guilty ones of the tragedy, 12 persons were indicted, among them two hall designers, who were accused of "directly endangering lives of other people" and faced up to 12 years in prison.

In general, the experts concluded that the major catastrophe was due to errors in the design, which changed several times in order to reduce the cost of building. It was also demonstrated that the company was aware of the problems and needed to clear the snow from the roof of the building, but ignored the warnings, not wanting to take on additional expenses (Kā Polijas..., 2013).

Thinking about safety and durability of constructions - the basic condition of the building longevity and sustainability in the future, the Latvian government should react adequately.

These problems are also in tune with the present political situation in the country and the world. They clearly show that the society has forgotten about the signals which should not be ignored and the problems should be noticed and solved in time. The society which does not understand or does not want to understand the problems has to be addressed and convinced.

By analysing them, it appears that the company is oblivious to the existence of economic laws to the business environment. Thus, for example:

- Law of value (lowest price problem in the building area);

- Law of expanded reproduction - "It is necessary to develop and expand production, constantly researching the needs of society";

- Intensive Development Law - "As the resources of our planet are limited, the ill-considered extensive or incomplete use of them may lead to the collapse of manufacturing and global natural disasters.";Law of interest - "positive cooperation with any human being can be best achieved if the people's interests - moral, material, social, etc. are are taken into consideration; 
- Law of harmonization of interests - " harmonious cooperation and development will only be achieved if the parties cooperate (buyer - seller, employer - employee, entrepreneur - state, etc.)". Participants will have consistency and common interests.

\section{Possible cause and consequence analysis of Maxima supermarket tragedy}

Possible causes and consequences of Maxima supermarket tragedy was analised from many specialists and scientists from Riga Technical University and Latvia University of Agriculture (Pakrastins, Gaile from RTU, Steinerts, Kreilis, Ozola, Skadins, Gusta from LUA) (Steinerts, Pakrastins...2011, Gusta...2014, Annotations...2014) Reflective scheme of causes and consequences of Maxima supermarket tragedy are shown in Figure 4. Reflective scheme of causes of Maxima supermarket tragedy are swown in Figure 5 and reflective scheme of consequences of Maxima supermarket tragedy are swown in Figure 6.

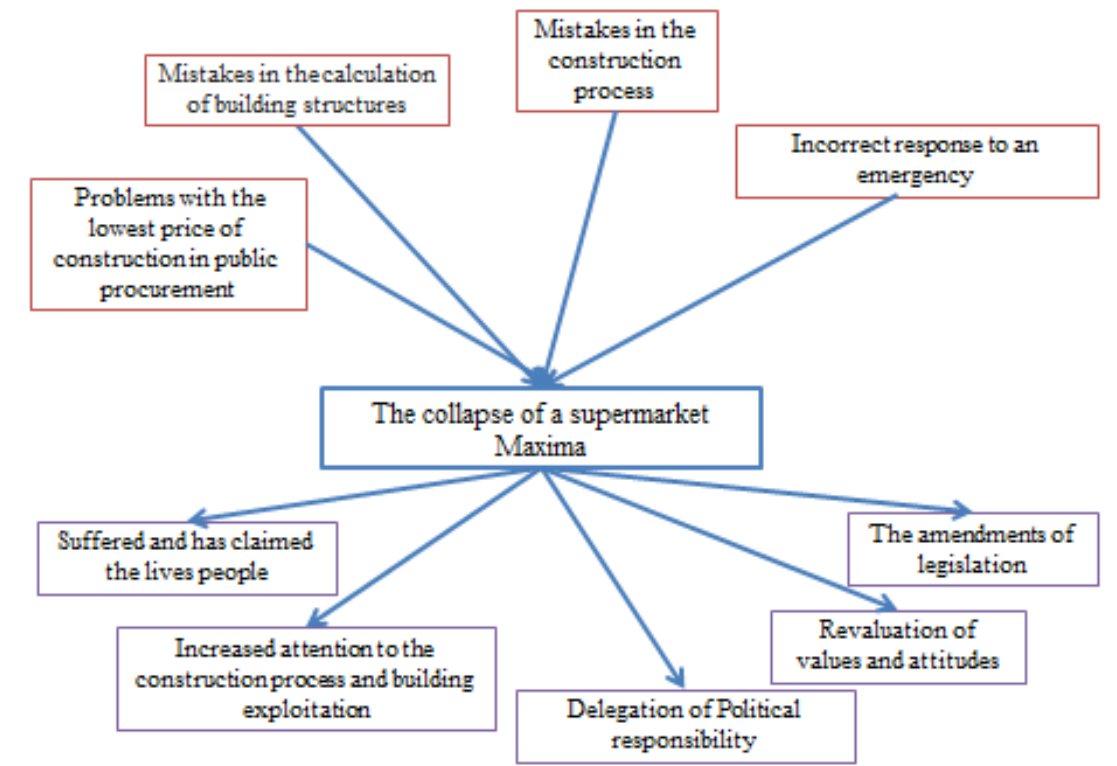

Figure 4. Reflective scheme of causes and consequences of Maxima supermarket tragedy (Source: by the author)

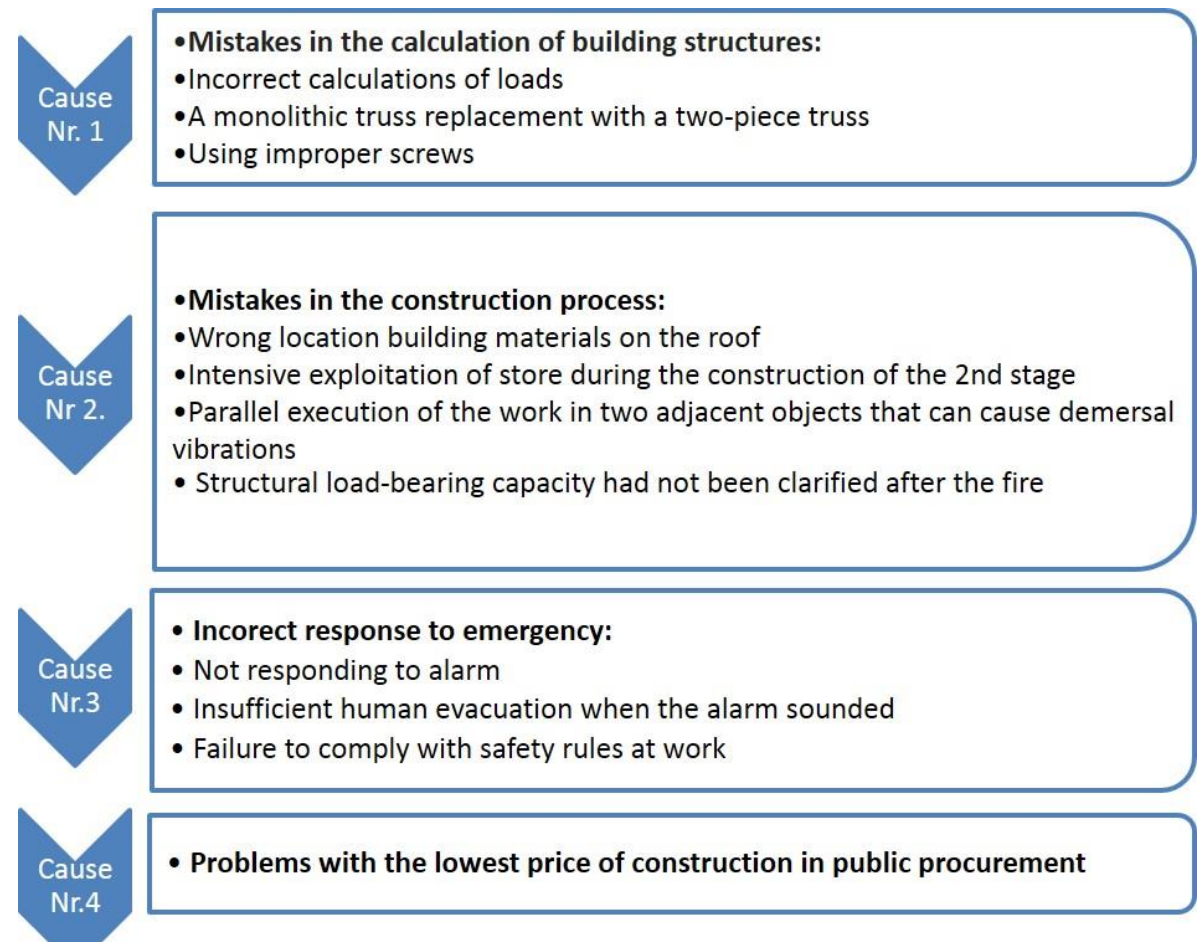

Figure 5. Reflective scheme of causes of Maxima supermarket tragedy (Source: by the author) 


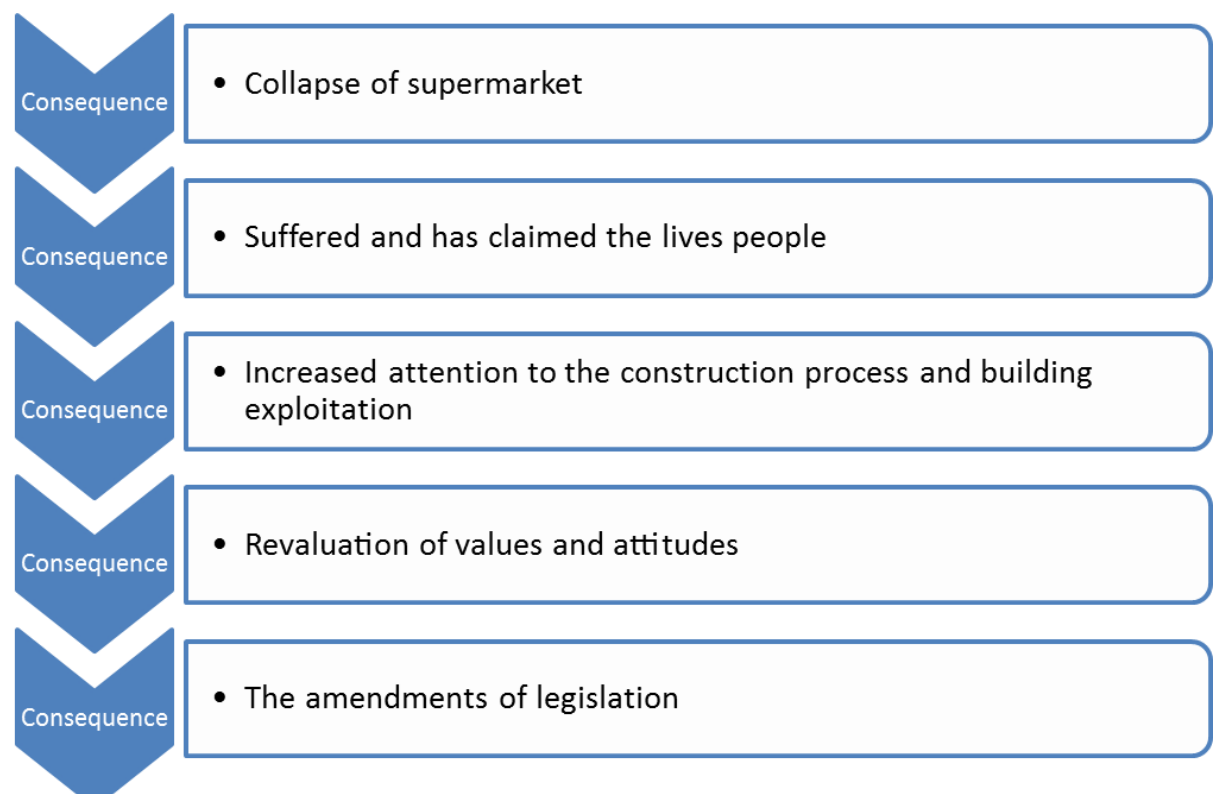

Figure 6. Reflective scheme of consequences of Maxima supermarket tragedy (Source: by the author)

According to the author the main causes of Maxima supermarket tragedy were:

- mistakes in the calculation of the building structures:

- mistakes in the construction process;

- $\quad$ incorrect response to an emergency;

- problems with the lowest price of construction in public procurement;

- the other reasons.

The main consequences of the Maxima supermarket tragedy are:

- $\quad$ collapse of the supermarket in Zolitude;

- causing human suffering and claiming the lives of people;

- increased attention to the construction process and building exploitation;

- revaluation of values and attitudes;

- the problems with the lowest price of construction in public procurement;

- the long introduction of the Eirocodes in Latvia;

- the other reasons.

\section{CONCLUSIONS}

The author's main conclusions and recommendations arising from the results of students' and teachers' study regarding the tragedy:

- Necessary to restore building inspection in Latvia. The lack of independent control of building sites. Simultaneous public building construction and exploitation is not allowed. How was it possible to allow large-scale construction work to take place on the roof while inside the store there were several dozen people? Completely inadequate staff response to the alarms. Alarms sounded, but the shop staff responsible reacted incorrectly. People were not evacuated in time.

- Problems of structural design and control. If substantial changes were made in the structures in the project (the side truss was split into two parts), it was mandatory to do iterative calculations and carry out reapproval of the project. The need to carefully analyze construction materials and conditions, such as checking the strength of the steel bolts class. It should be noted the designing work involves high level of responsibility and great work load, and the professionals are remunerated inadequately. Too little attention has been paid to the supporting structures for safety and sustainability. For public building design and construction the constructive solutions should be introduce in such constructive solutions of overload: upon the first noticeable appearance of distortion.

- Problems with Public procurement. Nowadays in construction the wrong slogan is dominating, and the prevailing principle is that the best offer is the cheapest one. There shall be no material savings at the expense of people's safety.

- Problems with delegation of responsibility in all levels.

- Important to improve the legislation in Latvia's building sector (Building Law).

- Necesity to implementate of Eurocode standarts in Latvia (Steinerts et al., 2011) and use them in practice. 
Note: Introduction of the Eirocodes in Latvia is taking long time, some significant structures have already been designed in compliance with the Eurocodes, and these projects are currently under construction. Examples include the Latvian National Library project "Castle of Light" (LNB 2005), the "Z-Towers" multifunctional high-rise building, the reconstruction of Riga Motor Museum (RMM 2011) and Riga South Bridge, with the longest span reaching 110 m (Riga City Council 2012).

In conclusion, the author wishes to express her belief that society as a whole will be able to identify, measure and draw the right conclusions from this tragic human and economic lesson.

\section{REFERENCES}

1. Annotations of Results of the Research carried out at The Department of Architecture and Building Faculty of Rural Engineering during 2014. Faculty of Rural Engineering, Latvia University of Agriculture

2. Brown, C. B., Elms, D. G. 2015. Engineering decisions: Information, knowledge and understanding. Structural Safety, Vol. 52, Part A, pp. 66-77.

3. Gusta, S. 2014. Safety And Durability Of Constructions - the Basic Condition of The Building Longevity and Sustainability In The Future Book of abstracts of the 6th International Conference on Safety and Durability of Structures. Wrocław, Poland.

4. Latvia mourns victims of Riga supermarket collapse Available at: http://news.bbcimg.co.uk/media/images/71281000/jpg/ 71281211 71281210.jpg (accessed on 01/11/2014).

5. Latvian Association of Structural Engineers (2014) L.Pakrastiņš Priekšlikumi būvniecības nozares profesionālās vides sakārtošanai. Available at: http://lbpa.lv/2013/11/priekslikumi-buvniecibas-nozares-profesionalas-videssakartosanai/ (accessed on 27/11/2013)

6. Latvian Association of Structural Engineers. 2011. Riga, LBPA, [cited 26 September 2012]. Available from Internet: http://lbpa.lv

7. Ratay, R. T., Peraza, D. B. 2013. Investigation and Analysis of Structural Collapses. Encyclopedia of Forensic Sciences, pp. 461-465. http://dx.doi.org/10.1016/B978-0-12-382165-2.00150-1

8. Regulation (EU) No 305/2011 of the European parlament and of the council [online] Available at: http://eurlex.europa.eu/LexUriServ/LexUriServ.do?uri=OJ:L:2011:088:0005:0043:EN:PDF (accessed on 01/11/2009).

9. Steinerts A., Pakrastinsh L., Gaile L., 2011. Implementation of Eurocode standarts in Latvia, Proceedings of the International Scientific Conference Civil Engineering'11 of Latvia University of Agriculture, Vol. 3, pp. 144-149, Jelgava.

10. The Baltic Times. 2014. Lawsuit filed in Maxima aftermath Available at: http://baltictimes.delfi.lv/news/articles/34011 (accessed on 01/11/2013).

11. The Capital. 2013. Kā Polijas varas iestādes rīkojās pēc Maximas traǵēdijai līdzīgās 2006. gada janvāra traǵēdijas Katovicē [online]. Available at: http://blog.kapitals.lv/2013/11/25/ka-polijas-varas-iestades-rikojas-pec-maximastragedijai-lidzigas-2006-gada-janvara-tragedijas-katovice (accessed on 25/11/2013). 